\title{
TWO RAMESSIDE STELAE AT THE GRAND EGYPTIAN MUSEUM (GEM 9295 \& 9444)
}

\author{
Marwa KAFAFY \\ Egyptology, Faculty of Archaeology, Ain-Shams University, Cairo, Egypt \\ E-mail: Marwa.Kafafy@arch.asu.edu.eg
}

\begin{abstract}
Two funerary stelae, preserved in the Grand Egyptian Museum, are studied, both show the same individual named pi3y. With their provenance unknown, their style allows to date to the $19^{\text {th }}$ and $20^{\text {th }}$ Dynasties. The first GEM 9295 with a pyramidion on top shows two main registers. The second GEM 9444 is a rounded-top stela with one large scene. The study includes transliteration, translation, and analysis of names and accompanying titles, as well a proposed reconstruction of the family tree of the owner of the first stelae.
\end{abstract}

\section{KEYWORDS}

Ramesside - Stelae - Nineteenth Dynasty pỉy - snny - t $3 y$-sryt

\begin{abstract}
الملخص
يهذف البحث إلى نشر ودر اسة لوحتين جنائزيتين

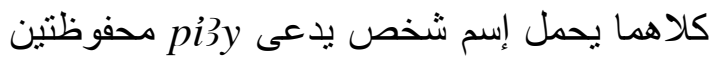
بالمتحف المصرى الكبير بالجيزة، مكان العثور

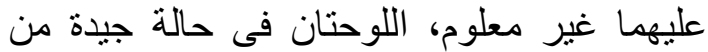

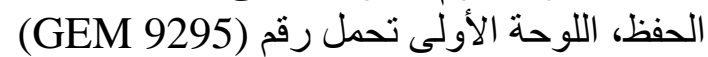

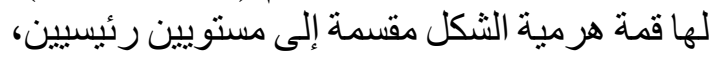

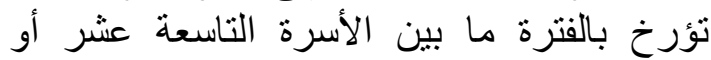

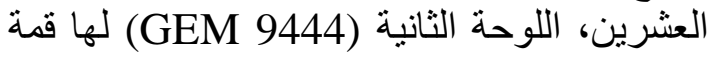
مستديرة ذات مستوى واحد وتؤرخ بنفس التونس الفترة

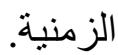
تقدم الدراسة نشراً لهاتين اللوحتين يتضمن قراءة الأباء

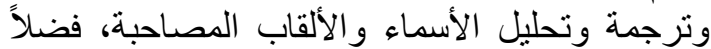
عن محاولة لفهم شجرة عائلة صاحب الالفياب اللوحة الأولي.
\end{abstract}

الكلمات الادالة الة الكيات

عصر الر عامسة، لوحة، الأسرة التاسعة عشرة، .t $3 y$-sryt ‘snny ،pi3y

\section{INTRODUCTION}

This paper studies two stelae of a person named $P i 3 y^{1}$ currently stored in the Grand Egyptian Museum. The provenance of the monuments is unknown. The two stelae are different in their style and form. The first one, GEM 9295, is rectangular with a pyramidion top and shows two registers representing the owner with his family members. This stela dates to the $19^{\text {th }}$ or $20^{\text {th }}$ Dynasties. The second one, GEM 9444, is a rounded-top stela. Its single scene shows the deceased in front of the god Osiris. It dates to the same period. The details of the two stelae are presented, focusing on the style, inscriptions, iconographic and epigraphic features, and the family tree of the owner.

${ }^{1}$ (TN.21.3.25.18, SR4/14137, GEM 9295), (22.3.25.8, SR4/14149, GEM 9444), PM, 803-048-240; 803 048245; Lieblein, J., Dictionnaire de noms hiéroglyphiques en ordre généalogique et alphabétique I, 626; Ranke, H. Die Ägyptischen Personennamen, I, 129 (25); Malek, J., Topographical Bibliography of Ancient Egyptian Hieroglyphic Texts, Statues, Reliefs and Paintings, IV, 62-63. 


\section{I- THE PYRAMIDION STELA (GEM 9295) Description and texts}

The stela GEM 9295 is rectangular with a pyramidion top. ${ }^{1}$ It is made of limestone measuring $56 \mathrm{~cm}$ in height and $37 \mathrm{~cm}$ in width; it is in a good state of preservation. The scenes are in raised relief, while the texts are in sunk relief. The scenes and texts are surrounded by an incised line which makes an outer frame of the stela. A dividing line separates the scene of the top triangle from the first register. A double line separates the first and second registers. The stela is adorned on all three levels by scenes and inscriptions. The hieroglyphic inscriptions were written in the Ramesside style.

\section{The triangular lunette}

The stela shows the $3 h t$ sign $\bigcirc$ at the apex. Below it, in the middle of the lunette, there are two identical jackal figures resting on shrines facing each other and depicting the god Inpw. ${ }^{2}$ Around the neck of each figure, the $s 3$ sign indicates protection. The name Inpw $\gamma^{\mathrm{mmm}}$ is written above the figures of the deity. His titles are written next to each shrine: next to the right shrine 10 约 级 110 " 1 imy-wt "who is in embalming tent" or "which is found in the scrolls"4. The Anubis on the right side represents the eastern horizon and the figure on the left the western horizon $^{5}$.

\footnotetext{
${ }^{1}$ JE. 36853, 54155, 38934; TN. 5/7/24/10, 14/3/25/6, 20/3/25/5, TN 21/6/24/17, 5/7/24/10, 28/5/25/2, 14/6/24/18, 20/3/25; GEM 5915, 8969, 2451, 9314, 8182, 23369; Radwan, A., 'Six Ramesside Stelae in the Popular Pyramidion-Form,' ASAE 71 (1987), pl. I [No. 400], II [No. 399], III [Tall-Basta No. 398]; Moursi, M., 'The Ramesside Stelae from Heliopolis,' GM 105, (1988), pl. I, II; Habachi, L., 'Tell Basta,' Supplément aux ASAE, Cahier No. 22, Le Caire, (1957), pl. XXXVIII [A]; Atallah, M., 'Eine Pyramidionstele eines Trompeters aus dem ägyptischen Museum in Kairo,' OLA 150/I, Leuven, (2007), Taf. I, Abb. I; Demarée, R.J., The Ax iqr n Ra-Stelae on Ancestor Worship in Ancient Egypt (1983), pl. I (= Stela Kestner Museum No. 2936], pl.V [A 16] (Stela Museo Egizio 50015), pl.VIII [A 27] (= Stela Fitzwilliam Museum E.SS. 38), pls. X [A 35] (= Stela British Museum 359), [A 36] (= Stela British Museum 372), [A 38] (= Stela Louvre E. 16362), pl. XI [A 42] (= Stela Martin von Wagner Museum H 3198); Berend, W.B., 'Principaux monuments du Musée Égyptien de Florence,' BEHE 51 (1882), pl.IX; Ali, N.O., 'Three Stelae from Ain-Shams,' in The Horizon Studies in Egyptology, in Honour of M.A. Nur El-Din, Vol. III (2009), pls. I, II, III, Fig. I, II, III; Berlev, O., The Egyptian Reliefs and Hodjash, S., Stelae in the Bushkin Museum of Fine Arts, Moscow, (2004), 79; Tosi M., \& Roccati, A., Stele Ealtre Epigrafi Deir el Medina n.50001-n.50262, Torino, (1972), no.50015M, 50069; Tawfik, T.S., 'A Special Type of Stelae from Saqqara as substitute for a tomb superstructure?,' ASAE 86, (2013), figs.1,2,5,7,8; BMHT 7, pl, 11 [No.308] ; BMHT 8, pl, 36 [No.301]; BMHT 9, pls. XV [No. 183], XXIII [No. 149], XLI [Nos. 372, 359]; BMHT 10, pl, 54 [No. 1188]; BMHT 12, pl.60 [No. 349], pl.84 [No.1184]; ÄMP 7291, Schoske, S., Auf immer und ewig:Visionen vom Jenseits im Alten Ägypten, Dietrich Wildung, Dettelbach, (2008).

${ }^{2}$ Anubis was commonly represented on the pyramidia of stelae during the Ramesside Period. The god was associated with the horizon as illustrated by the scene accompanying Chapter 117 of the Book of the Dead. There, Anubis leads the deceased towards a false-door that represents the entrance to the netherworld. When Anubis calls the deceased king, the earth opens its gates, so that the deceased king crosses the sacred area of Abydos where the entrance to the sky is located. According to the Pyramid Texts, the deceased follows the voice of Anubis who opens to him a gate in the sky toward the horizon. (Pyr 796 bc; 798c-799a)

${ }^{3} \mathrm{~Wb}$ III, 20 (17-18); Christina, A., Anubis: The God's Manifestation in the Iconographical and Literary Sources of the Pharaonic Period, Postgraduate Program of the University of the Aegean, Rhodes, (2018), 68-79.

In the word $s h$, the sign $\square$ was written instead of

${ }^{4} \mathrm{~Wb}$ I, 380, (1-4); Rössler-Köhler, U., 'Imiut,' LÄ III, 149-150

${ }^{5}$ Westendorf, W., 'Altägyptische Darstellungen des Sonnenlaufes auf der abschüssigen Himmelsbahn,' MÄS 10 (1966), 76-77.
} 


\section{The first register}

On the left side, Osiris is represented mummified and seated on his throne in the shape of the $h w t$ sign. He wears the Atef crown and holds the crook ${ }^{\top}{ }^{c} w t^{1}$ in the left hand and the flail $n h h$ in the right. The base of his throne takes the form of the $m 3^{2} t^{2}$ sign. In front of Osiris, an offering table $(h 3 w t)^{3}$ is depicted with two ds ${ }^{4}$ vessels below. There are two columns of inscriptions in front of Osiris and above him; his name and titles were written from right to left:

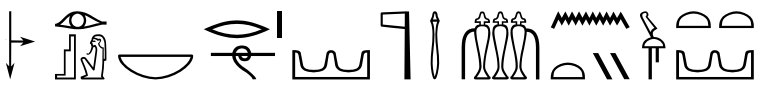

Wsir $n b$ r $3-s t^{3} w^{5}$ ntr- ${ }^{36}{ }^{6}$ hnty-imntt ${ }^{7}$

"Osiris, Lord of Ra-Setau ${ }^{8}$, the Great God, Foremost of the Westerners"

To the right of the offering table, three men are standing facing Osiris. Above each one of them, his name and title are captioned. The first one is P $i 3 y$ standing in adoration gesture $i 3 w^{9}$ or $d w^{10}{ }^{10}$. He is wearing the typical New Kingdom pleated garment and a short wig. ${ }^{11}$ His

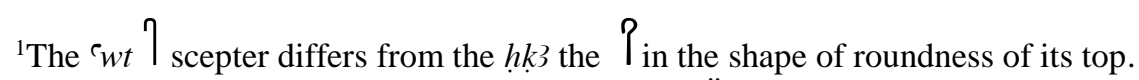

Hassan, A., 'Stöcke und Stäbe im Pharaonischen Ägypten bis zum Ende des Neuen Reiches,' MÄS 33, (1976)

${ }^{2} \mathrm{~A}$ relation between Osiris and Ma'at, is identified from the god's title " $n b{ }^{2} 3^{\mathrm{C}} t$, Lord of Justice", known since the Old Kingdom. This may explain his depiction over the Ma'at sign. Griffith, J.G. The Origin of Osiris, Berlin 1966, 118; Quirke, S., 'Translating Ma'at,' JEA 80, (1994), 228; LGG III, 639.

${ }^{3} \mathrm{~Wb}$ III, 226 (11); Wilson, P., Ptolemaic Lexikon, A Lexicographical Study of the texts in the Temple of Edfu, OLA 78, (1997). 703.

${ }^{4}$ This vessel looks closer to the vessel $d s$, which has a long neck that takes the shape of a funnel and has a slightly bloated body and a pointed base without handle. Surrounded by lotus flower, perhaps a sign of the desire to maintain the integrity of this pot as long as the flower is in good condition. Its purpose is to cool the water if the container contains water or to give the water a good taste if the container contains wine. Radwan, A., Die Kupfer- und Bronzegefäße Ägyptens, 89.1.

One or two placed on a stand, under the offering tables, appeared during the Ramesside period. CGC. 34505; JE. 3299, 27958, 34542, 41405, 20395, 32025; TN. 14/3/25/6, 26/2/25/5.

The lotus flower was attached to this vessel and it was depicted above it: CGC. 34506, 34517; JE. 27958, 36853, 65834, 68730, 72018, 86124, 87832; TN. 5/12/35/1, 10/6/24/11, 26/2/25/5, 30/1/15/13.

Or around it CGC. 34505; JE. 32025, 27958, 34542; TN. 14/3/25/6, 26/2/25/5.

${ }^{5} \mathrm{~Wb}$ II, 398,9-10

${ }^{6} \mathrm{~Wb}$ I, 360,7 (ff); CGC. 34503; JE 20395.

${ }^{7}$ The title hnty-imntt appeared from the time of the Old Kingdom and continue to be used until the Greco-Roman period. LGG, 783; CGC. 34182, 34503, 34505; JE. 18922, 32025, 2013; TN. 5/7/24/10, 10/6/24/11, 14/6/24/17. ${ }^{8}$ The word " Ro-Setau" is the name given by the ancient Egyptians to the other world and takes a determinative of the desert $几$, which refers to a region that extends from Giza and Saqqara. Since the Old Kingdom, it is associated with the god Osiris. Zivie, C.M., 'Ro-Setau,' $L \ddot{A} \mathrm{~V}, 305$.

The title $n b r 3-s t 3 w$ was used from the Old Kingdom until the Greek-Roman Period. LGG, 681.; TN. 14/10/69/1, $15 / 12 / 24 / 2$

${ }^{9} \mathrm{~Wb} \mathrm{I}, 28(1-5)$

${ }^{10} \mathrm{~Wb} \mathrm{~V}, 426(6)-428(7)$

${ }^{11}$ Brown, S., 'Hairstyles and Hair Ornaments,' in: Donovan, L. and McCorquodal, K (eds.), Egyptian Art, Principles and Themes in Wall Scenes, Cairo, (2000), 159.

It seems that this hairstyle appeared at the end of the $18^{\text {th }}$ Dynasty, from the reign of King Horemheb Martin, G.T., The Memphite Tomb of Horemheb, Commander-in-Chief of Tut'ankhamun. I. The Reliefs, Inscriptions and, Commentary, The Egypt Exploration Society Excavation, Memoirs 55, (1989), 33 [19-20], 86, 93, 139 [124]. This hairstyle disappeared before the mid- $19^{\text {th }}$ Dynasty. This hairstyle is distinctive due to it being taller and more dense than hairstyles during the second half of the $18^{\text {th }}$ Dynasty. This style was limited to Ramesside Saqqara sites. 
garment consists of two pieces. One covers the lower part of the body from the waist to the ankles, and is tied around the waist with a belt. The end of this kilt is arranged in a shape similar to an inverted triangle. The second piece of the garment covers the shoulders, and forms wide sleeves up to the elbow with abundant folds. ${ }^{1}$

Behind Pi3y stands $Y w p / Y p w$ with his right $\operatorname{arm}^{2}$ raised in adoration, while in his left hand he holds lotus flowers ${ }^{3} s n^{4}$ or $s \breve{s ̌ n} n^{5}$, which is common in the hands of both men and women on Ramesside stelae. ${ }^{6}$

$Y w p$ is depicted wearing a wig quite similar to the one worn by Pi3y. It is long and thick, with strands of hair hanging in a style characteristic to the time of Ramesses II. $^{7} Y w p$ wears a simple kilt ${ }^{8}$ that covers the lower part of his body. It has no folds and consists of two parts: a shorter one that covers the lower part of the body, and a longer one that reaches the top of his knees. Behind $Y w p$, stands another man with a shaved head; he is represented in a smaller

Āḥmd Ywns Mūḥamd Mūsá, lwhāat ālafrād fì 'ṣr ālr'āmsh- drāsah fnyah ațryah lmğmw'ah ālmtḥf ālmṣry bālqāhrah, risālit doktwrāh g̀yr mnšwrah, ğām't Ḥelwān, 2015, 398.

${ }^{1}$ Cruz-Uribe indicates that this kilt first appeared at the end of the $18^{\text {th }}$ Dynasty, during the reign of Tutankhamun, as found in many examples from Memphis. For instance, it may be seen in the decoration of the tombs of Horemheb, Maya and Tia (the overseer of the treasures of Ramesses II).

Cruz-Uribe, E., 'The Father of Ramses I: OI 11456', JNES 37 (3) (1978), 242; Martin, G. The Memphite Tomb of Horemheb, pls. 30 [18], 111(29); Martin, G., "The Tomb of Maya, Treasurer of Tut'ankhamun: Present Knowledge and Future Prospects," in A-P. Zivie, ed., Memphis et ses Nécropoles au Nouvel Empire. Nouvelles données, nouvelles questions. Actes du Colloque International CNRS. Paris, 11 octobre 1986 (Paris, 1988), 6972; Martin, G.T., The Tomb of Tia and Tia. A Royal Monument of the Ramesside Period in the Memphite Necropolis. EEM 58 (1997), 36, pls. 58, 164; Martin, G. T., 'The Tomb of Tia and Tia: Preliminary Report on the Saqqâra Excavations', JEA 70 (1984), p.8 It continued to appear in Ramesside representations during the first half of the $19^{\text {th }}$ Dynasty, especially between the reigns of Ramesses II and Merneptah.

JE 19772, 27958, 36853, 41399, 41400, 41405, 41406, 45557, 68574, 68730, 68737, 68742, 86124, 87832, 88666; TN. 10/6/24/11, 12/6/24/17, 20/3/25/5; Roeder, G., "Ramses II, als Gott: Nach den Hildesheimer Denksteinen aus Horbêt», ZÄS 61 (1926), pl. V [No. 2]; Clère, J.J., Nouveaux Documents Relatifs au Culte des Colosses de Ramsès II dans le Delta, Kêmi Revue du Philologie et d'Archeologie Égyptiennes et Coptes 11 (Paris 1950), 28, n. 1; Kayser, H., Die ägyptischen Altertümer im Roemer-Pelizaeus-Museum in Hildesheim (Hildesheim 1973), 61, Abb. 52; Clère, J.J., Kêmi 11, 36-38, pl. III [a]; Quibell, J.E., The Ramesseum, in British School of Archaeology in Egypt and Egyptian Research Account II (London 1898), 19-20, pl. XXVII [No. 2]; Farouk, A., «Zwei heliopolitanische Totenstelen und eine Opfertafel aus dem Neuen Reich», MDAIK 63 (2007), Abb. 2, Taf. 1 [b]; KRI III, 828-829; Exell, K., Soldiers, Sailors and Sandalmakers, 140 [No. 13], pl. 5 [a]; Černy, J., Egyptian Stelae in the Bankes Collection (Oxford 1958), No. 5; Gaballa, G.A., in Studies in Honour of H.W. Fairman, 42- 43, pl. 1 [a]; Ruffle, J., and Kitchen, K.A., in Orbis Aegyptiorum speculum, 56- 57, pl. III; Atallah, M., «Eine Pyramidionstele eines Trompeters aus dem ggyptischen Museum in Kairo», OLÄ 150/I (Leuven 2007), Taf. I, Abb. 1; Stewart, H.M., Egyptian Stelae, Reliefs and Paintings from the Petrie Collection: Part I, The New Kingdom (Warminster 1976), 31- 32, pl. 23; Koefoed-Petersen, O., Les Stèles Égyptiennes, 2829 [No. 23]; W. Spiegelberg and B. Portner, Aegyptische Grabsteine aus süddeutschen Sammlungen, II (Strasbourg 1904), 36-37, pl. XVIII [No. 26]; BMHT 12, 20, pls. 62- 63

${ }^{2}$ This name is not listed in Ranke, $P N$

${ }^{3}$ In Chapter $81 \mathrm{~A}$ of the Book of the Dead, the deceased wishes to turn into a lotus flower.

Allen, T.G., The Book of the Dead or Going Forth by Day: Ideas of Ancient Egyptians Concerning the Hereafter as Expressed in their Own Terms', in Studies in ancient oriental civilization 37 (Chicago 1974). 156.

${ }^{4}$ The lotus flower was initially associated with women, not men, and perhaps the oldest examples date to the $4^{\text {th }}$ Dynasty (Queen Mersankh III). Since Pepy II it appeared with men as well. Fischer, H.G., «A God and General of the Oasis on a Stela of the Late Middle Kingdom», JNES 16 (1957), 224, note 6.

${ }^{5} \mathrm{~Wb} \mathrm{~V}, 293$ (5-12), Brunner-Traut, E., 'Lotos', LÄ III, 1091

${ }^{6}$ The lotus flower appeared in the hands of men on Ramessid stelae. JE. 8781, 19772, 27820, 27958, 36853, 41402, 43569, 45557, 86124, 87829, 87832; TN. 3/7/24/17, 5/7/24/10.

The lotus flower appeared in the hands of women on Ramessid stelae. CGC. 34517; JE. 8781, 19772, 27958, 34182, 36853, 43569; TN. 3/7/24/17, 5/7/24/10, 12/6/24/17.

${ }^{7}$ BMHT 10, pl. 89 [No. 65356].

${ }^{8}$ This kilt did not appear on Ramesside stelae and was, perhaps, a military one. 
scale. This man is $\underline{d} h w t y-m s$. He is raising his right arm touching Ywp's elbow. He wears a kilt with folds covering the lower part of his body and holds in his left hand a goose. Seven columns of hieroglyphs text were incised above the three figures recording their names ${ }^{1}$ and titles. They are written from left to right:

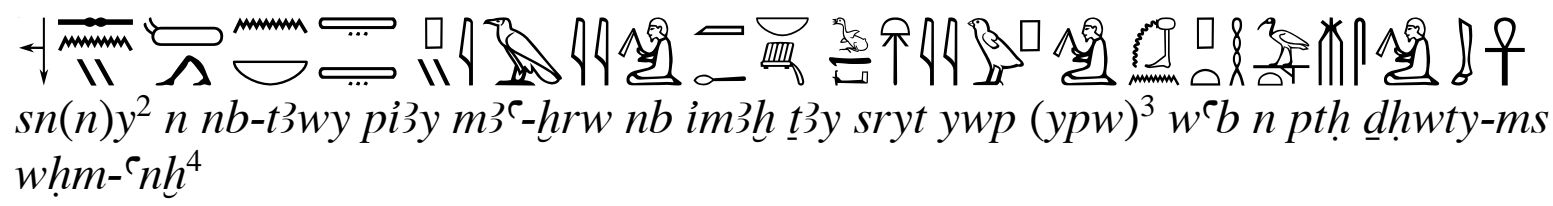

"Chariot-soldier (warrior) of the Lord of the Two Lands PiAy, true of voice, lord of blessing. Standard bearer Ywp. wab-priest of Ptah DHwty-ms, the one who repeats life."

\section{The second register}

The scene depicted on the second register is divided into two parts through an offering table. To the left of the offering table, Pi3y and his wife Rnnwt $(t)$ are represented seated on high back chairs with lion-paw legs connected by a horizontal bar and two vertical ones in the middle. ${ }^{5}$ Pi3y wears a hair wig ${ }^{6}$ that differs from the one represented in the first register. It has flowing ripples covering the ears and dropping on the shoulders. P $3 y$ extended his left arm towards the offerings while the right holds a folded handkerchief. ${ }^{7}$ His wife $\operatorname{Rnnwt}(t)$ is represented with a thick wig fixed over the head with a wreath. She wears a long transparent robe that reaches the top of her ankles, and she embraces her husband with both arms. Above them, six columns of hieroglyphic text are written from right to left:

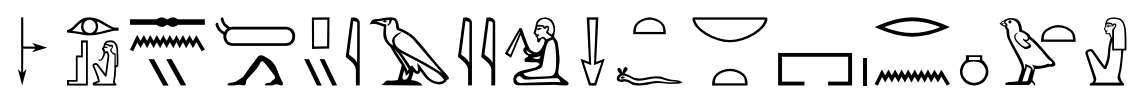

Wsir sn(n)y Pỉy snt.f nbt-pr ${ }^{8}$ Rnnwt(t)

"Osiris (deceased) charioteer (warrior) PiAy, his sister, the lady of the house Rnnwt(t)."

In front of them there is a table with stacked offerings. In the lower part, there are seven loaves of circular bread $Q_{p s n} .^{9}$ The loaves are interlaced as if they are arranged in two

\footnotetext{
${ }^{1}$ The determinative 资 refers to the deceased person.

${ }^{2}$ Lesko, L.H., A Dictionary of Late Egyptian III, USA, (1987), 63

${ }^{3}$ For the reading "ypw", see Malek, Topographical Bibliography, 62

${ }^{4} \mathrm{~Wb}$ I, 341, (3-7)

${ }^{5}$ Note the difference of levels for the bases of the two chairs.

${ }^{6}$ It seems that this hairstyle appeared at the end of the 18th Dynasty and was especially common during the reign of Horemheb. Martin, G.T., The Memphite Tomb of Horemheb, pls. 82, 85-86, 87-88, 89, 91, 94, 99, 101, 115; Ruffle, J., and K.A. Kitchen, 'The Family of Urhiya and Yupa, High Stewards of Ramesseum,' in Ancient Egypt: Studies in Honour of H. W. Fairman, in Orbis Aegyptiorum Speculu, (1979), pl. III.

${ }^{7}$ The folded handkerchief appeared on Ramesside stelae in the hands of men, not women, and it appears with seated men only.

Āḥmd Ywns Mūḥamd Mūsá, lwhāt ālafrād fì ‘ṣr ālr 'āmsh, 492.

${ }^{8}$ he $n b t-p r$ is a title for a married woman that was first introduced in the Middle Kingdom and continued to be used until the Ptolemaic period. It referred to wives, sisters and mothers. Leahy, A., 'Late Period Stelae in the Fitzwilliam Museum,' SÄK 8 (1980), 177; Robins, G., Women in Ancient Egypt, Cambridge, (1993), 53.; Černý, J., 'Consanguineous Marriages in Pharaonic Egypt,' JEA 40, (1954), 23-29

${ }^{9}$ The offering table is topped with seven loaves of psn bread. This reminds the seven meals of bread religious texts state that the deceased will eat in the netherworld: three on earth and four in the sky.

Pyr. 371; CT III, 51(173), 93 (188), 97(189), 106(192), 113(195), 137(203), 151(205); VI , 288(662), 364 (729). The distribution of these meals may differ from one text to another. CT VII, 225(1011)
} 
adjacent rows with four and three loaves respectively. The next level is composed of sacrificed ribs $\approx p r^{1}$; over the ribs, there is a bull's head ${ }^{2}$ and a thigh $\approx h p \breve{s .}^{3}$ At the top of the pile of offerings, there are stems and flowers of lotus $s \check{n} n$.

To the right of the offering table, there are five figures led by a person named Nht-imn. Nhtimn wears a military kilt and raises his right arm in a hailing gesture while in his left hand, he holds a bunch of lotuses. Behind him stands his sister Whmt-3ht. She holds lotus plants in her right hand and a bundle of lotus flowers in her left hand. Behind her stands her sister sxmt, who raises her arms in a worship gesture.

Their names and titles are written in two vertical columns and one horizontal line of hieroglyphs, which may be transcribed as follows:

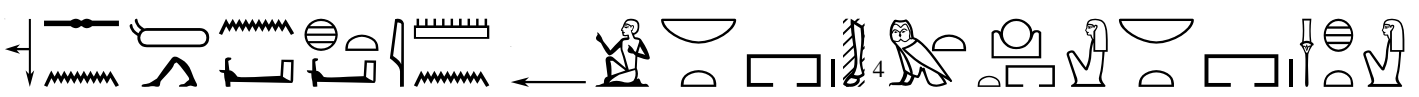

sn(ny) Nht-Imn nbt-pr Whmt-3ht $t^{5}$ nbt-pr shmt

"Charioteer (warrior) nht-Imn, lady of the house whmt-3ht, lady of the house shmt."

In front of Imn-nht, under the offering table, stands the small figure of a girl named Ipt$m w t .^{6}$ She stands in the adoration position and wears a long wig divided into three parts. Her hair tufts reach to her chest. To the left of the table, her name is recorded in a column. Between Whmt-3ht and shmt, another small figure shows a son whose name is written above his head $Y w p(Y p w){ }^{7}$

\section{General Commentary}

The stela presents a symbolical image of the universe; the base represents the earth, ${ }^{8}$ and its top is the sky. By ascending through the registers, the scenes on the stela show the transition of a person through life to death, and then to the afterlife. The lower register refers to life

Those offerings appeared in offering lists from the $4^{\text {th }}$ Dynasty until the end of the New Kingdom. Wb. I, 549 (18-21); Mohr, H.T., 'The Mastaba of Hetep-her-akhti. Study on an Egyptian tomb 4 chapel in the Museum of Antiquities Leiden,' in Mededelingen en verhandelingen van het Vooraziatisch-Egyptisch Genootschap "Ex Oriente Lux” 5 (Leiden 1943), 90; James, T.G.H., 'The Mastaba of Khentika called Ikhekhi,' in Archaeological Survey of Egypt Memoir 30, London, (1953), 62, pl. 36. The pattern has become popular on Ramesside stelae. CGC. 34505, 34517; JE. 18922, 19772, 27958, 20395, 32025, 34542, 41403, 41405, 48845, 52542; TN. 3/7/24/17, 5/7/24/10, 14/3/25/6.

${ }^{1}$ It first appeared on the offering table of $h^{e}-b 3 w-s k r$ from the $3^{\text {rd }}$ Dynasty, and, by the end of the $4^{\text {th }}$ Dynasty, it was known as spHt nt spr "the full part of the ribs". It was one of the favourite parts of ancient Egyptians.

Hassan, S., Giza V, 99 (14); Wb. IV, 101 [14-15]; S. Hassan, Excavation at Giza, Vol. VI/II, 353.

It appeared only on stelae of the first half of the $19^{\text {th }}$ Dynasty, especially in the reign of Seti I and Ramesses II. JE. 18922, 34542; TN. 14/3/25/6.

${ }^{2}$ It appeared only on the stelae of the first half of the $19^{\text {th }}$ Dynasty, especially in the reign of Ramesses II. JE. 3299, 18922; TN. 14/3/25/6.

${ }^{3}$ It appeared during the Old Kingdom until the Late Period. It symbolised the elimination of enemies for resurrection. It had been done by Horus for his father Osiris (as seen in Pyramid Texts).

Mercer, S.A., The Pyramid Texts in Translation and Commentary (New York 1952), 253 [No. 1635 a]; Gordon, A, 'The Ka as an Animating Force,' JARCE 33 (1996), 34.

${ }^{4}$ Lieblein, J., Dictionnairede noms hiéroglyphiques en ordre généalogique et alphabétique I, Leipzig, (1871), 207 (626).

${ }^{5}$ Lieblein, J., Dictionnaire de noms hiéroglyphiques en ordre généalogique et alphabétique , I, 626

${ }^{6}$ This name is not listed in Ranke, $P N$

${ }^{7}$ This name is similar to what was recorded in the first level and written with the same signs.

${ }^{8}$ Westendorf, W.,"Altägyptische Darstellungen des Sonnenlaufes, 16 
where the determinatives of Pi3y and his family members' names as well as their titles indicate their living status. The stage of death is represented in the upper register where $P i 3 y$, $Y w p$, and $d h w t y-m s$ stand in front of Osiris. Determinatives behind their names indicate that they are dead, which is perhaps a reference to the deceased's entry into the netherworld as represented in Spell 125 from the Book of the Dead. ${ }^{1}$ Finally, the stage of the resurrection is symbolised by the depiction of the 3ht sign at the top of the stela. The horizon is the portal to the netherworld, separating the sky from the earth, ${ }^{2}$ where the sun enters the $d w 3 t .{ }^{3}$ The stela with a pyramidion on its top reflects the initial stage of the sun's journey in the day. ${ }^{4}$ The representations on the pyramidion are dedicated to the solar cult. Hence this stela combines the two main components of a tomb: the Osirian aspect representing death and the netherworld and the solar aspect which stands here for resurrection. ${ }^{5}$

As for the symbolic orientation of the stela, the depiction of the god Osiris on Ramesside pyramidion stelae was always on the left side (the west) and the deceased on the right side (the east). This determines the orientation of the stela itself. ${ }^{6}$

Since the Middle Kingdom, stelae symbolised the tomb of the deceased himself, ${ }^{7}$ while stelae with a pyramidion top are characteristic of the architecture of the New Kingdom tombs in Saqqara. ${ }^{8}$ Gaballa and Malek also hinted that the shape of these stelae may represent the front view of a tomb when looking at it from the east. ${ }^{9}$ Tawfik stated that most of the owners of these stelae were of modest rank, and did not hold any important titles; for none of them a tomb is attested. ${ }^{10}$ This is especially common for those who were buried inside shafts. ${ }^{11}$ However, this is not the case for Pi3y, the owner of the stela, who had an important military title that only people of high rank held.

\footnotetext{
${ }^{1}$ Allen, T.G., The Book of the Dead or Going forth by day, London, (1968), 97-101

${ }^{2} \mathrm{CT}$ VI, 354a

${ }^{3}$ Binder, S., 'The Hereafter: Ancient Egyptian Beliefs with special references to the Amdouat,' BACE 6 (1995), 7

${ }^{4}$ Franke, D., 'When the sun goes down: early solar hymns on a pyramidion stela from the reign of Sekhemrashedtawy sobekemsaf,' in: M. Marée (ed.), The second intermediate period (thirteenth-seventeenth Dynasties), OLA 192 (210), 288.

${ }^{5}$ Tawfik, T., 'Some Remarks about the Stelae of the New Kingdom Necropolis at Saqqara,' SASAE 34, (2005), Vol. II,.385.

${ }^{6}$ There is no specific direction for placing deities on the stelae, on either the right or the left side, Munro, P., Die Spätägyptischen Totenstelen, ÄF 25 (1973), 32.

It is noted that some of the stelae are distinguished by the fact that the left side, where Osiris is usually depicted, represents the west. In contrast, the right side, where the deceased is usually depicted, represents the east. CGC. 34505, 34506; JE. 2013, 3299, 20395, 32025, 34182, 34542, 36853; TN. 3/7/24/17, 35/7/24/10, 10/6/24/11, 12/6/24/17, 14/10/69/1, 14/3/25/6, 15/12/24/2, 20/3/25/5. Sometimes, the opposite happens, CGC. 34503, JE. $8784,19772,48845$

${ }^{7}$ Müller, H.W., 'Die Totendensteine des Mittleren Reiches, ihre Genesis, ihre Darstellungen und ihre Komposition,' MDAIK 4 (1933), 166-169.

${ }^{8}$ Manassa, C., 'Two Unpublished Memphite Relief Fragments in the Yale Art Gallery,' SAK30, (2002), 266

${ }^{9}$ Gaballa, G., 'False-door Stelae of some Memphite Personnel,' SAK 7, (1979), 41-52; Malek, J., 'Brief communications, New Kingdom pyramidia,' JEA 76, (1990), 180-184.

${ }^{10}$ Tawfik, T., 'Some Remarks about the Stelae of the New Kingdom Necropolis at Saqqara,' SASAE 34, (2005), Vol. II, 385.

${ }^{11}$ Kampp, F., Die Thebanische Nekropole, Theben XIII, 1996, Chap. V, Nr. 9, p. 108; Tawfik, T.S., 'A special type of Stelae from Saqqara as substitute for a tomb superstructure,' ASAE 86, (2015), 400.
} 
The presence of Inpw, "Anubis", on the pyramidion of the stela is a Ramesside feature. There may be one ${ }^{1}$ or two ${ }^{2}$ figures of the god. Hölzl ${ }^{3}$ suggests that the purpose of depicting Anubis on the pyramidion of the stelae is to guard and protect the deceased and the stela. Radwan $^{4}$ believes that the representation of "Anubis" alone or with the horizon sign was added to ensure the coming of the sunlight. The jackal-deity is the one who brings light and life in the realm of Osiris. He is thus considered the sun of the netherworld and is also responsible for pulling the sun boat in the netherworld. ${ }^{5}$

\section{The Names and Titles}

The name of the owner of the stela, Pi3y, is mentioned twice: in the first register, preceded by the title $s n(n) y$, and in the second register preceded by the title $w \operatorname{sir} s n(n) y$ (deceased). The signs and the way of writing are the same.

The name Pi3y was common during the New Kingdom, especially during the $19^{\text {th }}$ and $20^{\text {th }}$ Dynasties. ${ }^{6}$ Concerning the identification of $P i 3 y$, a man with the same name was mentioned in texts of the southern temple in Buhen, dating to the third year of the reign of King

\footnotetext{
${ }^{1}$ Radwan, A., 'Six Ramesside Stelae in the Popular Pyramidion-Form', pl.I,II, VI; Moursi, M., 'The Ramesside Stelae from Heliopolis', pl.1,2; Ali, N.O., 'Three Stelae from Ain-Shams,' in Horizon Studies in Egyptology in Honour of M.A. Nur el-Dein, Vol. III (Cairo 2009), pl.I,(fig 1), pl.II (fig.2); Tawfik, T., 'Some Remarks about the Stelae of the New Kingdom Necropolis at Saqqara', fig.8; GEM 8969; 2451 (SR 5/9540); 9314 ( SR 4/14135, JE 14780); 23369 (SR 4/13994); SR 4/11884 (JE 20220); TR 28.5.25.2; SR 4/12069 (JE 38934); BMHT 12, pl.60-61 (349).

${ }^{2}$ BMHT 7, pl.II (308); BMHT 10 pl. $54-55$ (1188); TR 21.6.24.17; JE 54155 (SR 4/11428); Atallah, M., 'Eine Pyramidionstele eines Trompeters aus dem ägyptischen Museum in Kairo', taf.1; Tosi, M. and Roccati, A., Stele e alter epigrafi di Deir el Medina n. 50001 - n. 50262, in Catalogo del Museo egizio di Torino 1 (Torino 1972), 50069.

${ }^{3}$ Hölzl, R., in SCIE, I, 288.

${ }^{4}$ Inpw is called "nb-shhd" "lord of light" and " $n b-\ulcorner n h "$ "lord of life", which indicates his role in lighting the kingdom of Osiris in order to restore life. Since the New Kingdom, he was also a messenger and guide to spirits of deceased people and was associated with sunrise and sunset (this explains the horizon sign on the apex) for the sake of resurrection and the revival of life. Radwan, A., "Six Ramesside Stelae in the Popular PyramidionForm", 228.

${ }^{5}$ Tawfik, T., 'Some Remarks about the Stelae of the New Kingdom Necropolis at Saqqara', SASAE 34, (2005), 385.

${ }^{6}$ For the name piAy during the New Kingdom: Daviers, B.G., Genealogies and personality characteristics of the workmen in the Deir-el-Medina community during the Ramesside period, PhD thesis, University of Liverpool 1996, pp.212ff. Pi3y is a servant in the place of truth, his wife Nfrt-xaw, Ramesses II's reign. PM I, 2, p.744; Bierbrier, M.L., 'PiAy in Cambridge', JEA 68 (1982), 85-92. PlAy, Overseer of the herds of Amun$\mathrm{Ra}$ at Thebes, the royal scribe of herds of Amenophis I, his wife $t 3-w r t, 19^{\text {th }}$ Dynasty.

PM I, 1, 412-413; Gauthier, H., 'sur une campagne de fouilles à Drah Abou'l Neggah en 1906', BIFAO 6 (1908), 148-162; Fakhry, A., 'A Report on the Inspectorate of Upper Egypt', ASAE 46 (1947), 25-54; Kampp, F., Die thebanischen Nekropole: Zum Wandel des Grabgedankens von der XVIII. bis zur XX. Dynastie (= Theben, 13). 2 vols. Mainz am Rhein: Verlag Phillip von Zabern, 1966, 584, fig. 102 (p. 201).

PiAy, Scribe of the offering table of the Lord of the two Lands, 20th Dynasty.

PM I, 1, 446; Kampp, F., Die thebanischen Nekropole: Zum Wandel des Grabgedankens von der XVIII. bis zur XX. Dynastie (= Theben, 13). 2 vols. Mainz am Rhein: Verlag Phillip von Zabern, 1966, 610-611, fig. 377 (p. 484).

Graefe, E., 'Fouilles de l'Assassif', CDE 50 (1975), 99-100, 13-64; Habachi, L., ASAE IV (1958), 349.

PiAy The scribe of the table of Amon of the lord of the two lands, 20th or 21st Dynasty.

PM I, 1, 383; Kampp, F., Die thebanischen Nekropole: Zum Wandel des Grabgedankens von der XVIII. bis zur XX. Dynastie (= Theben, 13). 2 vols. Mainz am Rhein: Verlag Phillip von Zabern, 1966. 570-571, fig. 454 (p. 561).

PiAy Scribe of the granary of the Temple of Amun, reign of Ramesses II, 19th Dynasty, his wife wbht PM I, 1, 344-345; Kampp, F., Die thebanischen Nekropole: Zum Wandel des Grabgedankens von der XVIII. bis zur XX. Dynastie (= Theben, 13). 2 vols. Mainz am Rhein: Verlag Phillip von Zabern, 1966, 540-541, fig. 435-437, 307 (p. 416).
} 
Merenptah-Siptah. ${ }^{1}$ He held military positions, which is evident from his titles $t 3 j \underline{h w}(h r)$ wnmj $n$ nswt "Fan-bearer to the right of the king" and $k \operatorname{tn}$ tpj $n(h m . f)$ "First charioteer (of his majesty)". 2

The owner of these stelae Pi3y may have held the titles of "First charioteer" and "Fan-bearer to the right of the king"; there is no objection to combining these two titles. ${ }^{3}$ He may have served as the personal guard of the King or the Vizier of the North as Kitchen indicated. ${ }^{4}$ So He may have been contemporary to King Ramesses II and continued until the third year of the rule of Siptah.

PiAy may have been a military person who held many positions with the military titles $t 3 j$ $h w(h r)$ wnmj $n$ nswt, ktn tpj $n(h m . f)$, sn (n)y n nb-t3wy.

In the Louvre Museum (E124-N502), a wooden statue of an individual called P $3 y$ dates from the reign of Ramesses II. ${ }^{5}$ Another statue within the private collection of Albert Husson in Lyon, ${ }^{6}$ studied by Clère, also preserved the title iry- 3 n pr-nsw "doorkeeper of the royal palace". Regarding holders of the title $t 3 y$-sryt, Ramesside texts state that the person titled with this military distinction can go in and out in the halls of the royal palace, ${ }^{7}$ which indicates that the person was entrusted with entering the royal palace in order to protect the king. ${ }^{8}$ Such title may have belonged to the stelae's owner, since his military position also implied the protection for the king. The name of Ramesses II (wsr-M3 $\left.t-r^{\top}-s t p-n-r^{\complement}\right)$ appeared in the statues' inscriptions, matching the provisional dating of PiAy to the reign of this king. The title $s n(n) y$ "charioteer" is recorded on the stela twice in two different forms. In the first register, it is $\stackrel{\text { IIm }}{\mathrm{II}} \operatorname{sn}(n) y$; in the second register, it is mmm $\Omega \operatorname{sn}(n) y$. Both variants are common in texts of the New Kingdom. ${ }^{9}$

Pi3y was proud of this title, as implied by its double recording on this stela: once in the first register (the mortal life) $s n(n) y$ and once in the second register (the afterlife) wsir $s(n) i$. His son Nht-Imn inherited this position from him.

\footnotetext{
${ }^{1}$ PM VII, 2, 134-135; Randall-Maciver, D., \& Leonard Wooley, C., Buhen, Philadelphia 1911, pl.16.

${ }^{2}$ KRI IV, 366 (7, 9); Kahn, D., A Geo-Political and Historical Perspective of Merneptah's Policy in Canaan, Proceeding of the International Conference held at the University of Haifa, 2010, 264,266.

Another view is that this title belongs to a person named " $p 3 y$ "

Safronov, A., 'New titles of the great chancellor Bay', JEA 99 (2013), 290-295.

${ }^{3}$ As is the case with Amenmope. Safronov, A., "New titles of the great chancellor Bay", 290.

${ }^{4}$ Kitchen, K. A., Review of R. Drews, The End of the Bronze Age: Changes in Warfare and the Catastrophe ca. 1200 B.C. (Princeton, 1993)

${ }^{5}$ Mekawy, A., 'The statue of the Doorkeeper of the palace Pi3y (Louvre E 124)', SAK 44 (2015), 283-295

${ }^{6}$ Clère, J. J., "Deux statues gardiennes de porte d'époque Ramesside", JEA 54 (1968), 139

${ }^{7}$ Caminos, RA., Late-Egyptian Miscellanies, London 1954 (BrownStud 1), 400-410; Gardiner, A., LateEgyptian Miscellanies, Bruxelles 1937 (BAe 7), pp. 107.4-109.10; Blackman, AM. Peet, TE., Papyrus Lansing: A Translation with Notes, JEA 11, 1925, 291-293; Bresciani, E., Letteratura e poesia dell'antico Egitto. Cultura e società attraverso i testi, Torino, 3rd edition, 1999, 336-337;

Brunner, H., Ancient Egyptian Education, Wiesbaden 1957, 175-176.

${ }^{8}$ Mekawy, A., 'The statue of the Doorkeeper of the palace Pi3y', 284

${ }^{9}$ Gardiner, A.H., Egyptian Hieratic Texts, series 1: Literary Texts of the New Kingdom, part 1, The Papyrus Anastasi and The Papyrus Koller, Leipzig 1911, 1,23,6; Erichsen, W., Papyrus Harris I, Bibliottheca Aegyptiaca V, Brussels 1933, 31 (8); Gardiner, A.H., Late Egyptian Miscellanies, Bibliottheca Aegyptiaca VII, Brussels 1937, 3,6,3-4; KRI 2,81,12; KRI 2, 64, 4; KRI 1, 5, 11; KRI 1, 6, 9; KRI 5, 22, 10.
} 
This title appeared during the $18^{\text {th }}$ Dynasty, ${ }^{1}$ and continued to be used until the $21^{\text {st }}$ Dynasty. ${ }^{2}$ It was often paired with the title of $t 3 y$-sryt "Standard-bearer", person had both titles together. ${ }^{4}$ This could be the case of $P i 3 y$. This position was held by a person with a prominent social standing, who must have been from a family with a military background. ${ }^{5}$ Many appear to have had an Asian origin. ${ }^{6}$

This title appears in the descriptions of the battle of Qadesh from the time of Ramesses II, ${ }^{7}$ the first Libyan campaign on the walls of the Medinet-Habu Temple of Ramesses III ${ }^{8}$, the campaign against the Sea People recorded in the same temple, ${ }^{9}$ as well as in the Papyrus Harris I. ${ }^{10}$

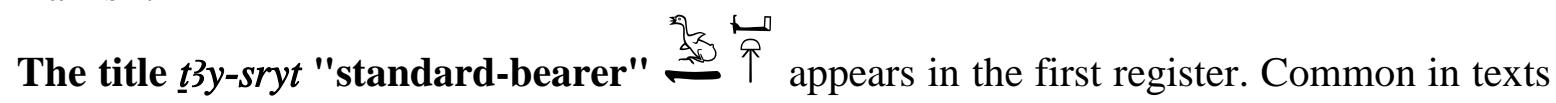
of the New Kingdom, this title appeared at least during the Amarna Period and then in texts only in Ramesside period ${ }^{11}$, specifically from the $19^{\text {th }}$ dynasty from Saqarra. ${ }^{12}$ The word $s r y t$, "standard" ${ }^{13}$, appeared only with the title $t 3 y$-sryt "standard-bearer ". Faulkner $^{14}$ believes that the word sryt is not an Egyptian word and has a foreign origin, being perhaps derived from a Hyksos word.

The Egyptian army during the Ramesside Period was a regular army. ${ }^{15}$ It was divided into three groups, each group composed of two hundred soldiers who served under the command of $t 3 y$ sryt,"standard-bearer". Each division of the army had its own standard. ${ }^{16}$

\footnotetext{
${ }^{1}$ Helck, W., A stele of the Viceroy Wsr-St.t, JNES 14, 1955, 22 ff; Helck, W., documents of the 18th Dynasty, Berlin 1955-58, 1343-44; Helck, W., documents of the 18th Dynasty, translation to issues 17-22, Berlin 1961, 50; Manuelian, P. Der., Studies in the Reign of Amenophis II., HÄB 26, 1987, 155-58; Leprohon, R., Stelae II. The New Kingdom to the Coptic Period, CAA, Mainz 1991, 25,632; Wente, E., Letters from Ancient Egypt, Atlanta 1990, 27; Beylage, P., Structure of the royal stele texts from the beginning of the 18th Dynasty to the Amarna period, ÄAT 54, Wiesbaden 2002, $417 \mathrm{ff}$.

${ }^{2}$ Spiegelberg, W., 'Letters of the 21st Dynasty from El-Hibe', Z̈̈S 53 (1917), 16;

Jansen-Winkeln, K., Inscriptions of the Late Period, Part I, The 21st Dynasty, Wiesbaden 2007, 208.

${ }^{3}$ Schulman, A.R., Military rank, title and organization in the Egyptian New Kingdom, PhD, University of Pennsylvania 1962, 96-97

${ }^{4}$ Shulman, A.R., 'The Egyptian Chariotry, reexamination', JARCE 2 (1963), 79

${ }^{5}$ Shulman, A.R., 'The Egyptian Chariotry, reexamination', 77

${ }^{6}$ Manassa, C., 'Two Unpublished Memphite Relief Fragments in the Yale Art Gallery', SAK 30 (2002), 266

${ }^{7}$ KRI II,33:5; 64:4; 81:12

${ }^{8}$ KRI V, 22:10

${ }^{9}$ KRI V, 44:11

${ }^{10}$ Erichsen, W., Papyrus Harris I: Hieroglyphisthe Transkription, Brussels, 1933, 36:14

${ }^{11}$ Lesko, L.H., A Dictionary of Lat Egyptian IV, 104; Wb IV, 192 (13); A.H. Gardiner, Late Egyptian Miscellanies, Bibliottheca Aegyptiaca VII, Brussels, 1937, 6,13,3.

${ }^{12}$ Allam, S., ASAE 71, 1987, 5-12, pl. I-II, 13-19, pl. III-IV; Bakir, M., Egyptian Epistolography, Le Caire 1970, BdE 48, pls. 1-3; KRI, I, 322-324; Wente, E., Letters from Ancient Egypt, Atlanta, 1990, 114 f; AH Gardiner, Late-Egyptian Miscellanies (Bibliotheca Aegyptiaca VII), Brussels, 1937, xiii and 1-12a; RA Caminos, Late-Egyptian Miscellanies (Brown Egyptological Studies, I), London 1954, 1- 34

${ }^{13}$ This standard appeared for the first time during the $18^{\text {th }}$ Dynasty within the inscriptions of the Temple of the Queen Hatshepsut and was made of wood or metal and sometimes provided with real feathers. This standard was used in land and marine processions.

Faulkner, R.O., 'Egyptian Military Standards', JEA 27(1941), 13-14

${ }^{14}$ Faulkner, R.O., 'Egyptian Military Standards', JEA 27 (1941), 13.

${ }^{15}$ Faulkner, R.O., 'Egyptian Military Organization', JEA 39(1953), 41

${ }^{16}$ Faulkner, R.O., 'Egyptian Military Organization', JEA 39(1953), p.45
} 


\section{The Family of Pi3y}

The stela is a good family recording of Pi3y. It includes names of nine individuals whose interrelations are not mentioned. According to the standards of Ramesside stelae, one may expect the depiction of brothers in the upper register and children in the lower one. ${ }^{1}$ Therefore, in the upper register, the owner of the stela $P i 3 y$ may be represented with his two brothers: $Y w p(Y p w)$ and $\underline{d} h w t y-m s$. In the second register, Pi3y is represented with his wife Rnnwt $(t)$ and in front of them, their five children: Imn-nht, Whmt-3ht, shmt, and two relatively small figures of Ipt-mwt and $Y w p(Y p w)$. The latter has the same name as his uncle.

Location. Linguistic and technical analyses of the elements of the stela indicate that the stela originated from the Memphite area $^{2}$ according to the following facts:

- Asiatics were often soldiers in the Egyptian army, and most had tombs in the Memphite necropolis.

- The title $t 3 y$-sryt "Standard-bearer" appeared only in the texts of Saqqara during the $19^{\text {th }}$ Dynasty.

- The pyramidion-topped stelae first appeared in Saqqara.

- The name of Ptah was mentioned in the title $w^{\complement} b n$ Pth.

- The term " $r 3-s t 3 w "$ in the title of Osiris may refer to Saqqara.

\section{Date.}

Pi3y lived during the $19^{\text {th }}$ and $20^{\text {th }}$ Dynasties; this stela may be dated to the $19^{\text {th }}$ Dynasty due to:

- The pyramidion-topped stelae attested from the $19^{\text {th }}$ Dynasty.

- The bull's foreleg, head of the bull, ribs and geese on the offering table characteristic to the first half of the $19^{\text {th }}$ Dynasty (reigns of Seti I and Ramesses II).

- The $d s$ vessels commonly used during the first half of the $19^{\text {th }}$ Dynasty, gradually disappearing from the $20^{\text {th }}$ Dynasty.

- The kilt type of Pi3y was commonly used from the second half of the $18^{\text {th }}$ Dynasty, especially during the reign of Horemheb. It continued to be represented on Ramesside stelae of the first half of the $19^{\text {th }}$ Dynasty (reigns of Ramesses II and Merneptah).

\section{II- THE ROUNDED-TOP STELA (GEM 9444) General Description (Figure 2)}

The rounded top stela, ${ }^{3}$ measuring $32.5 \mathrm{~cm}$. in height and $25 \mathrm{~cm}$ in width, is made of limestone. The inscriptions are in sunk relief, while the figures are in raised relief. The stela

\footnotetext{
${ }^{1}$ EA 146, HTBM 9, pl. XLVII, KRI I, 344; EA 292, HTBM 12, pl.58-59; EA 351, HTBM 12, pl.66-67; EA 351, HTBM 12, PL.60-61, 349; EA 1347, HTBM 12, pl.38-39.

${ }^{2}$ Martin, G. T., Raven, M. J., Aston, B.G., and Van Dijk, J., 'The Tomb of Maya and Meryt: Preliminary Report on the Saqqâra Excavations', JEA 74, 1988, 1-14

Martin, G. T., 'Excavations at the Memphite Tomb of Horemheb, 1975: Preliminary Report', JEA, 62 (1976), pl.II, 2; Martin, G. T., 'Excavations at the Memphite Tomb of Horemheb, 1975: Preliminary Report', JEA 62 (1976), pl.III,2; Málek, J., 'The Tomb-Chapel of Hekamaetre-Neheh at Northern Saqqara,' SAK 12 (1985), fig.3

${ }^{3}$ The rounded-top stela is attested from the $1^{\text {st }}$ Dynasty onwards and became a common type of stelae from the Middle Kingdom up to the Roman Period. Hölzl, R., op. cit, p.285

There were many opinions concerning the origin of the curved shape of the top of the stela. Some assume association with the cellars of rock cut tomb chambres in the Upper Egypt. Others draw attention to the primitive gods' tombs. For instance, Alexander Badawi linked them to the shrine of "Anubis". Westendorf linked it to the skyline assuming that the upper part of the stela represents the sky (and its goddess Nut, which is sometimes
} 
is in a good state of preservation except for a damaged small part of its left edge. The representation and text are surrounded by an incised line which makes the external frame. There is no separating line between the lunette and the scene. Three incised columns of text attest the name and title of the owner of the stela:

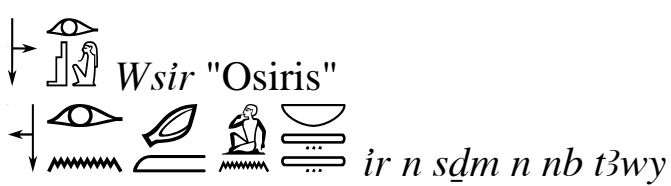

"Making by the servant ${ }^{1}$ of the Lord of the Two Lands"

On the left side, Osiris is represented in a mummified form, standing on a $m 3^{`} t$ base form. $\mathrm{He}$ wears his traditional $3 t f$ crown. In his right hand, he holds a sceptre that could be the ' $w t$ or the $h k 3$; it is difficult to determine either of them since its top is missing. In his left hand, he holds the $n h h$. In front of Osiris, stands the owner of the stela Pi3y with a shaved head and a long kilt. This iconography is typical of the time of Ramesses II. Pi3y's name is written in front of him. In his left hand, he holds a $k b h^{2}$ vessel for the pouring water ritual, ${ }^{3}$ while in his right hand he holds a bell censer. ${ }^{4}$ The scene could be interpreted as the deceased asking Osiris for his revival. ${ }^{5}$

\section{General Commentary sdim Pi3y}

The title $s \underline{d m} / s \underline{d} m y$ "Servant" appears during the New Kingdom, ${ }^{6}$ and is attested either alone or in conjunction with kings or deities. ${ }^{7}$ It was common during the Ramesside Period,

depicted on the top of the stela in a curved form) and the lower part represents the earth (or Geb). The top and bottom of the stela are connected with the wAs sceptres which symbolise pillars of the sky.

Badawy, A., 'La Stèle Funéraire sous l'Ancien Empire: son origine et son Fonctionnement', ASAE 48 (1948), 228-232; Westendorf, W., Altägyptisch Darstellungen des Sonnenlaufes auf der abscüssigen Himmelsbahn, $M \dddot{A} S 10$ (1966), 22.

${ }^{1}$ Wb IV, 389, 8; Malek, J., Topographical Bibliography, p.63

${ }^{2}$ The $k b h$ vessel was often seen on Ramesside stelae, especially during the reign of King Ramesses II JE. 19772; TN. 10/6/24.

3 "Libation" ritual $k b h$ is attested from the Predynastic times. It was common during the New Kingdom and lasted until the Greco-Roman Period. It seems to be related to the snTr "censing" ritual, and associated with Osiris. The water was known as Osiris's secretion as long as it is related to the Nile. Libation was also associated with ablution and return to life to Osiris and symbolised creation and rebirth.

Borghouts, J.F., "Libation", in LÄ III (Wiesbaden 1980), 1014; Blackman, A.M., 'The Significance of Incense and Libation in Funerary and Temple Ritual', Z̈̈S 50(1912), 70-71; Assmann, J. 'Das Leichensekret des Osiris : zur Kultischen Bedeutung des Wassers im Alten Ägypten', BDÉ 138(2003), 5; Goyon, J., 'Le Cérémonial Glorification d'Osiris du Papyrus de Louvre I 3079', BIFAO 65 (1967), 101; Dalia, A., 'The Refreshing Water of Osiris', JARCE 29 (1992), p.182-183.

${ }^{4}$ It is a vessel that widens at the top from which the flame comes out. BMHT 9, pls. XX [No. 139] (= KRI IV, 124), XXI [No. 164] (= KRI III, 386-388), XXV [No. 167] (= KRI III, 206-207), XXVI [No. 163] (= KRI III, 211), XXVII [No. 154] (= KRI IV, 123-124), XLIX [No. 366], LI [No. 314]; BMHT 10, pls. 41 [No. 556] (= KRI III, 80), 94 [No. 795] (= KRI VII, 409), 96 [No. 1680]; BMHT 12, pl. 84 [No. 1184]; M. Tosi and A. Roccati, Stele, 292 [No. 50069] (KRI I, 399); L. Habachi, The Qantir Stela of the Vizier Rahotep and the Statue Ruler-of-Rulers, $A b b$. I.

${ }^{5}$ Bonnet, H., «Die Bedeutung der Raüeerungen in ägyptischen kult», ZÄS 67 (1931), 116-117.

${ }^{6}$ H. Lesko, L., A Dictionary of Late Egyptian, II, 126.

${ }^{7} \mathrm{~Wb}$ IV, 389, 6-11 
especially in texts of Ramesses II from Memphis ${ }^{1}$ and Thebes. ${ }^{2}$ It is likely that the owner of the second stela was the same person mentioned in two litters, one from the reign of Ramesses I, ${ }^{3}$ the second from the reign of Ramesses $\mathrm{II}^{4}$ found at Saqqara, as he has the same name and title.

\section{CONCLUSION}

The first stela belongs to a military individual called $P i 3 y$, He held a high military rank, and a high-ranked title snny "Chariot soldier". He lived between the $19^{\text {th }}$ and the $20^{\text {th }}$ Dynasties, most probably, from the reign of Ramesses II until the third year of the reign of MerneptahSiptah. The first stela gives evidence for the family of this prominent military officer. Among the family members, his brothers and children are depicted. The brothers hold military and priestly titles that are characteristic of the Ramesside Period, especially during the $19^{\text {th }}$ Dynasty.

The second stela depicts another person who is also named Pi3y performing the ritual of pouring water and censing before Osiris. The stela belongs to a Memphite tomb; the carving style, the attire of the figures, all point to the $19^{\text {th }}$ Dynasty. These details, along with the preserved personal name and title, suggest that it originate from a tomb in the Memphite necropolis.

\footnotetext{
${ }^{1}$ Caminos, R.A., Late-Egyptian Miscellanies, London 1954 (BrownStud 1), 497-501; Chabas, F., Correspondance des scribes Kaouisar et Bekenptah, in: Mélanges égyptologiques. III,2, Dejussieu 1873, S. 130139; Gardiner, A.H., Late-Egyptian Miscellanies, Brussels, 1937 (BAE 7), S. XXI, 136,6-137,7; Brugsch, H., Die Aegyptologie. Abriss der Entzifferungen und Forschungen auf dem Gebiete der aegyptischen Schrift, Sprache und Alterthumskunde, Leipzig 1897, 223-227; Bakir, M., Egyptian Epistolography, Le Caire 1970, BdE 48, pl. 6, VIII, pl.9, XII; Allam, S., Melange Mokhtar, Bd.1, BdE 97.1, 1985; Helck, W., Materialien zur Wirtschaftsgeschichte des Neuen Reiches, III, Wiesbaden 1963 (483); Wente, E., Letters from Ancient Egypt, Atlanta, 1990, 33F, 113; Janssen, J.J., Nine Letters from the Time of Ramses II, OMRO 41, 1960, 35, 40; KRI III, 230.

2 Budge, E.A.W., Facsimiles of Egyptian Hieratic Papyri in the British Museum; London 1925, Tf. 48-52; Gardiner, A.H., Late-Egyptian Stories, Brussels, 1981 (Reprint von 1932) (BiAe 1); S. IX, 1-9; Möller, G., Hieratische Lesestücke für den akademischen Gebrauch; Bd. 2, Literarische Texte des Neuen Reiches; Leipzig 1927, Tf. 21-24; Blok, H.P., De beide Volksverhalen van Papyrus Harris 500 verso; Leiden 1925; Borghouts, J.F., Egyptische sagen en verhalen, Bussum 1979, 81-85; Bresciani, E., Letteratura e poesia dell'antico Egitto. Cultura e società attraverso i testi; Torino, 3. Auflage, 1999, 390-393; Brunner-Traut, E., Altägyptische Märchen. Mythen und andere volkstümliche Erzählungen; München, 9. Auflage, 1990, 55-60, 287-289; Erman, A., Die Literatur der Aegypter. Gedichte, Erzählungen und Lehrbücher aus dem 3. und 2. Jahrtausend v. Chr.; Leipzig 1923, S. 209-214; Galán, J.M., Four Journeys in Ancient Egyptian Literature; Göttingen 2005 (LingAegM 5), S. 95-132; Grandet, P., Contes de l'Egypte ancienne, Paris 1998, S. 89-95; Lalouette, C., Textes sacrés et textes profanes de l'ancienne Égypte; Bd. 2, Mythes, contes et poésies, s.1. 1987, S. 181-185; Lefebvre, G., Romans et contes égyptiens de l'époque pharaonique. Traduction avec introduction, notices et commentaire, Paris 1988 (= 1949), 114-124; Lichtheim, M., Ancient Egyptian Literature. Bd. 2, The New Kingdom; Berkeley, Los Angeles, London 1976, 200-203; Schott, S., Altägyptische Liebeslieder. Mit Märchen und Liebesgeschichten; Zürich 1950, S. 188-192; Schüssler, K, Pharao Cheops und der Magier. Altägyptische Märchen und Erzählungen; Zürich 2003, 108-114; Wente, E.F., in: W.K. Simpson, The Literature of Ancient Egypt. An Anthology of Stories, Instructions, and Poetry; New Haven, London, 2. Auflage, 1973, 85-9 ${ }^{3}$ pCairo 58057, KRI I, 238, Möller, G., Hieratic Reading Pieces for Academic Use, III, Leipzig 1910, 8 (3.); Maspero, G., ZÄS 19, 1881, 119; Allam, S. Hierat Ostraca and papyri from the Ramesside period, documents on legal life, vol. 1, Tübingen 193, 287 ff., Vol. 2, 86; Helck, Materials on the economic history of the New Reich, III, Wiesbaden 1963 (501); Wente, E., Letters from Ancient Egypt, Atlanta, 1990, 112 f.

${ }^{4}$ pCairo 58058, Bakir, M., Egyptian Epistolography, Cairo, 1970, Vol 48, pl. 6; Allam, S., Melange Mokhtar, Vol. 1, Vol. 97.1, 1985; Helck, Materials on the economic history of the New Reich, III, Wiesbaden 1963 (483); Wente, E., Letters from Ancient Egypt, Atlanta, 1990, 113.
} 


\section{BIBLIOGRAPHY}

1- Āḥmd Ywns Mūḥamd Mūsá, lwhāt ālafrād fì 'ṣr ālr 'āmsh-drāsah fnyah atryah lmğmw'ah ālmthf ālmṣry bālqāhrah, risālit doktwrāh ġyr mnšwrah, ğām 't Ḥelwān 2015.

2- Ali, N.O., 'Three Stelae from Ain-Shams', in The Horizon Studies in Egyptology, in Honour of M.A. Nur El-Din, Vol. III (2009), 65-75.

3- Allen, T.G., The Book of the Dead or Going Forth by Day: Ideas of Ancient Egyptians Concerning the Hereafter as Expressed in their Own Terms', in Studies in ancient oriental civilization 37 (Chicago 1974).

4- Assmann, J. 'Das Leichensekret des Osiris: zur Kultischen Bedeutung des Wassers im Alten Ägypten', BDÉ 138(2003).

5- Atallah, M., 'Eine Pyramidionstele eines Trompeters aus dem ägyptischen Museum in Kairo', in OLA 150/I (Leuven 2007).

6- Badawy, A., 'La Stèle Funéraire sous 1'Ancien Empire: son origine et son Fonctionnement', ASAE 48 (1948), 228-232.

7- Berend, W.B., "Principaux monuments du Musée Égyptien de Florence, BEHE 51 (1882)

8- Berlev, O., The Egyptian Reliefs and Hodjash, S., Stelae in the Bushkin Museum of Fine Arts, Moscow 2004.

9- Beylage, P., Structure of the royal stele texts from the beginning of the 18th Dynasty to the Amarna period, ÄAT 54, Wiesbaden 2002.

10- Bierbrier, M.L., 'PiAy in Cambridge', JEA 68 (1982), 85-92.

11-Binder, S., 'The Hereafter: Ancient Egyptian Beliefs with special references to the Amdouat', BACE 6 (1995).

12- Blackman, A.M., 'The Significance of Incense and Libation in Funerary and Temple Ritual', Z̈̈S 50 (1912), 69-75.

13- Blackman, AM. Peet, TE., 'Papyrus Lansing: A Translation with Notes', JEA 11 (1925), 284-298.

14- Blok, H.P., De beide Volksverhalen van Papyrus Harris 500 verso, Leiden, 1925.

15- Borghouts, J.F., Egyptische sagen en verhalen, Bussum 1979.

16- Bresciani, E., Letteratura e poesia dell'antico Egitto. Cultura e società attraverso i testi; Torino, 3. Auflage, 1999.

17- Brunner, H., Ancient Egyptian Education, Wiesbaden 1957.

18- Brown, S., 'Hairstyles and Hair Ornaments', in Donovan, L. and McCorquodal, K. (eds.), Egyptian Art, Principles and Themes in Wall Scenes, Cairo 2000.

19- Brugsch, H., Die Aegyptologie. Abriss der Entzifferungen und Forschungen auf dem Gebiete der aegyptischen Schrift, Sprache und Alterthumskunde, Leipzig 1897.

20-Brunner-Traut, E., Altägyptische Märchen. Mythen und andere volkstümliche Erzählungen; München, 9. Auflage, 1990.

21-Budge, E.A.W., Facsimiles of Egyptian Hieratic Papyri in the British Museum; London, 1925.

22- Brunner-Traut, E., 'Lotos', LÄ III, 1091

23-Caminos, R.A., Late-Egyptian Miscellanies, London, 1954 (BrownStud 1).

24- Černý, J., 'Consanguineous Marriages in Pharaonic Egypt', JEA 40 (1954), 23-29.

25- Černy, J., Egyptian Stelae in the Bankes Collection, Oxford, 1958). 
26- Chabas, F., Correspondance des scribes Kaouisar et Bekenptah, in: Mélanges égyptologiques. III,2, Dejussieu 1873.

27- Clère, J. J., 'Deux statues gardiennes de porte d'époque Ramesside', JEA 54 (1968), 135-148.

28-Clère, J.J., Nouveaux Documents Relatifs au Culte des Colosses de Ramsès II dans le Delta, Kêmi Revue du Philologie et d'Archeologie Égyptiennes et Coptes 11 (Paris 1950).

29- Cruz-Uribe, E., 'The Father of Ramses I: OI 11456', JNES 37 (3) (1978), 237-244.

30- Dalia, A., 'The Refreshing Water of Osiris', JARCE 29 (1992), 181-190.

31-Demarée, R. J. The $3 h$ ik $r r n R^{\complement}$-Stelae on ancestor worship in ancient Egypt, Egyptologische uitgaven, 1983.

32-Exell, K. 'Soldiers, Sailors and Sandalmakers.' A Social Reading of Ramesside Period Votive Stelae (2009).

33- Fakhry, A., 'A Report on the Inspectorate of Upper Egypt', ASAE 46 (1947), 25-54

34- Farouk, A., 'Zwei heliopolitanische Totenstelen und eine Opfertafel aus dem Neuen Reich', MDAIK 63 (2007), 1-7.

35- Faulkner, R.O., 'Egyptian Military Standards', JEA 27(1941), 12-18.

36- Fischer, H.G., 'A God and General of the Oasis on a Stela of the Late Middle Kingdom', JNES 16 (1957), 223-235.

37- Gaballa, G., 'False-door Stelae of some Memphite Personnel', SAK 7(1979), 41-52

38- Galán, J.M., Four Journeys in Ancient Egyptian Literature, Göttingen, 2005.

39-Gardiner, A.H., Egyptian Hieratic Texts, series 1: Literary Texts of the New Kingdom, part 1, The Papyrus Anastasi and The Papyrus Koller, Leipzig 1911.

40- Gardiner, A.H., Late Egyptian Miscellanies, Bibliottheca Aegyptiaca VII, Brussels 1937.

41- Gardiner, A.H., Late-Egyptian Stories, Brussels, 1981 (Reprint von 1932).

42- Gauthier, H., 'sur une campagne de fouilles à Drah Abou'l Neggah en 1906', BIFAO 6 (1908), 148-162.

43- Gordon, A, 'The Ka as an Animating Force', JARCE 33 (1996), 31-35.

44- Goyon, J., 'Le Cérémonial Glorification d'Osiris du Papyrus de Louvre I 3079', BIFAO 65 (1967), 89-156.

45- Grandet, P., Contes de l'Egypte ancienne, Paris, 1998.

46- Griffith, J.G. The Origin of Osiris, Berlin, 1966.

47- Habachi, L., "Tell Basta", Supplément aux ASAE, Cahier No. 22 (Le Caire 1957).

48- Hassan, A., "Stöcke und Stäbe im Pharaonischen Ägypten bis zum Ende des Neuen Reiches", MÄS 33 (1976).

49- Helck, Materials on the economic history of the New Reich, III, Wiesbaden, 1963.

50- Helck, W., 'A stele of the Viceroy Wsr-St.t', JNES 14, 1955, 22 ff.

51- Helck, W., documents of the 18th Dynasty, translation to issues 17-22, Berlin, 1961.

52- Helck, W., Materialien zur Wirtschaftsgeschichte des Neuen Reiches, III, Wiesbaden 1963.

53- James, T.G.H., "The Mastaba of Khentika called Ikhekhi", in Archaeological Survey of Egypt Memoir 30 (London 1953).

54- Janssen, J.J., Nine Letters from the Time of Ramses II, OMRO 41, 1960. 
55- Kahn, D., A Geo-Political and Historical Perspective of Merneptah's Policy in Canaan, Proceeding of the International Conference held at the University of Haifa, 2010.

56- Kampp, F., Die thebanischen Nekropole: Zum Wandel des Grabgedankens von der XVIII. bis zur XX. Dynastie (= Theben, 13). 2 vols. Mainz am Rhein: Verlag Phillip von Zabern, 1966.

57- Kayser, H., Die ägyptischen Altertümer im Roemer-Pelizaeus-Museum in Hildesheim , Hildesheim , 1973.

58- Lalouette, C., Textes sacrés et textes profanes de l'ancienne Égypte; Bd. 2, Mythes, contes et poésies, s.1. 1987.

59- Leahy, A., 'Late Period Stelae in the Fitzwilliam Museum', $S \ddot{A K} 8$ (1980), 169-180.

60- Lefebvre, G., Romans et contes égyptiens de l'époque pharaonique. Traduction avec introduction, notices et commentaire, Paris, 1988 (=1949)

61- Leprohon, R., Stelae II. The New Kingdom to the Coptic Period, CAA, Mainz, 1991.

62- Lesko, L.H., A Dictionary of Late Egyptian III, USA 1987.

63-Lieblein, J., Dictionnairede noms hiéroglyphiques en ordre généalogique et alphabétique I, Leipzig 1871.

64- Málek, J., 'The Tomb-Chapel of Hekamaetre-Neheh at Northern Saqqara,' SAK 12 (1985), 43-60.

65- Malek, J., 'Brief communications, New Kingdom pyramidia', JEA 76 (1990), 180184.

66- Malek, J., Diana, M., and Elizabeth M., '"Topographical Bibliography of Ancient Egyptian Hieroglyphic Texts, Statues, Reliefs and Paintings Volume VIII: Objects of Provenance Not Known: Statues.', Osiris 802 (1999).

67- Manassa, C., Two Unpublished Memphite Relief Fragments in the Yale Art Gallery, SAK30 (2002), 255-267.

68- Manuelian, P. Der., Studies in the Reign of Amenophis II., HÄB 26 (1987), 155-58.

69- Martin, G. T., 'Excavations at the Memphite Tomb of Horemheb, 1975: Preliminary Report', JEA 62 (1976), 5-13.

70-Martin, G. T., 'The Tomb of Tia and Tia: Preliminary Report on the Saqqâra Excavations', JEA 70 (1984), 5-12.

71- Martin, G. T., Raven, M. J., Aston, B.G., and Van Dijk, J., 'The Tomb of Maya and Meryt: Preliminary Report on the Saqqâra Excavations', JEA 74, 1988, 1-4.

72- Martin, G., "The Tomb of Maya, Treasurer of Tut'ankhamun: Present Knowledge and Future Prospects," in A-P. Zivie, ed., Memphis et ses Nécropoles au Nouvel Empire. Nouvelles données, nouvelles questions. Actes du Colloque International CNRS. Paris, 11 octobre 1986 (Paris, 1988).

73-Martin, G.T., The Memphite Tomb of Horemheb, Commander-in-Chief of Tut'ankhamun. I. The Reliefs, Inscriptions and, Commentary, The Egypt Exploration Society Excavation Memoirs 55 (1989).

74- Martin, G.T., The Tomb of Tia and Tia. A Royal Monument of the Ramesside Period in the Memphite Necropolis. EEM 58 (1997).

75- Mekawy, A., "The statue of the Doorkeeper of the palace Pi3y (Louvre E 124)", SAK 44 (2015), 283-295.

76- Mercer, S.A., The Pyramid Texts in Translation and Commentary (New York 1952). 
77- Mohr, H.T., The Mastaba of Hetep-her-akhti. Study on an Egyptian tomb 4 chapel in the Museum of Antiquities Leiden, in Mededelingen en verhandelingen van het Vooraziatisch-Egyptisch Genootschap “Ex Oriente Lux” 5 ,Leiden, 1943.

78-Möller, G., Hieratic Reading Pieces for Academic Use, III, Leipzig, 1910.

79-Möller, G., Hieratische Lesestücke für den akademischen Gebrauch; Bd. 2, Literarische Texte des Neuen Reiches; Leipzig 1927.

80- Moursi, M., 'The Ramesside Stelae from Heliopolis', GM 105 (1988), 59-63.

81-Müller, H.W., 'Die Totendensteine des Mittleren Reiches, ihre Genesis, ihre Darstellungen und ihre Komposition"', MDAIK 4 (1933), 166-169.

82-Quibell, J.E., The Ramesseum, in British School of Archaeology in Egypt and Egyptian Research Account II , London, 1898.

83-Radwan, A., 'Six Ramesside Stelae in the Popular Pyramidion-Form', ASAE 71 (1987), 223-228.

84-Ranke, H., and Anneliese Biedenkopf-Ziehner. Die ägyptischen personennamen. Vol. 3. Glückstadt: JJ Augustin, 1935.

85- Robins, G., Women in Ancient Egypt, Cambridge, 1993.

86- Rössler-Köhler, U., 'Imiut', LÄ III, 149-150.

87- Ruffle, J., and K.A. Kitchen, 'The Family of Urhiya and Yupa, High Stewards of Ramesseum', in Ancient Egypt: Studies in Honour of H. W. Fairman, in Orbis Aegyptiorum Speculu, (1979), 55-74.

88-Safronov, A., 'New titles of the great chancellor Bay', JEA 99 (2013), 290-295.

89- Schoske S., Auf immer und ewig:Visionen vom Jenseits im Alten Ägypten, Dietrich Wildung, Dettelbach 2008.

90- Schott, S., Altägyptische Liebeslieder. Mit Märchen und Liebesgeschichten, Zürich 1950.

91-Schüssler, K, Pharao Cheops und der Magier. Altägyptische Märchen und Erzählungen, Zürich, 2003.

92- Schulman, A.R., Military rank, title and organization in the Egyptian New Kingdom, PhD, University of Pennsylvania, 1962.

93- Shulman, A.R., 'The Egyptian Chariotry, reexamination', JARCE 2 (1963), 75-98.

94- Jansen-Winkeln, K., Inscriptions of the Late Period, Part I, The 21st Dynasty, Wiesbaden, 2007.

95-Schott, S., Altägyptische Liebeslieder. Mit Märchen und Liebesgeschichten, Zürich 1950.

96-Schüssler, K, Pharao Cheops und der Magier. Altägyptische Märchen und Erzählungen, Zürich, 2003.

97- Wente, E.F., in: W.K. Simpson, The Literature of Ancient Egypt. An Anthology of Stories, Instructions, and Poetry, New Haven, London, 2. Auflage, 1973.

98- Stewart, H.M., Egyptian Stelae, Reliefs and Paintings from the Petrie Collection: Part I, The New Kingdom, Warminster, 1976.

99- Tawfik, T., 'Some Remarks about the Stelae of the New Kingdom Necropolis at Saqqara', SASAE 34, (2005), Vol. II.

100- Tawfik, T.S., 'A Special Type of Stelae from Saqqara as substitute for a tomb superstructure?', ASAE 86 (2013).

101- Tosi M., \& Roccati, A., Stele Ealtre Epigrafi Deir el Medina n.50001-n.50262, Torino, 1972. 
102- Tosi, M. and Roccati, A., Stele e alter epigrafi di Deir el Medina n. 50001- n. 50262, in Catalogo del Museo egizio di Torino 1 (Torino 1972).

103- W. Spiegelberg and B. Portner, Aegyptische Grabsteine aus süddeutschen Sammlungen, II (Strasbourg 1904).

104- Wente, E., Letters from Ancient Egypt, Atlanta 1990.

105- Westendorf, W.,'Altägyptische Darstellungen des Sonnenlaufes auf der abschüssigen Himmelsbahn', MÄS 10 (1966).

106- Wilson, P., Ptolemaic Lexikon, A Lexicographical Study of the texts in the Temple of Edfu, in OLA 78 (1997). 


\section{PLATES}

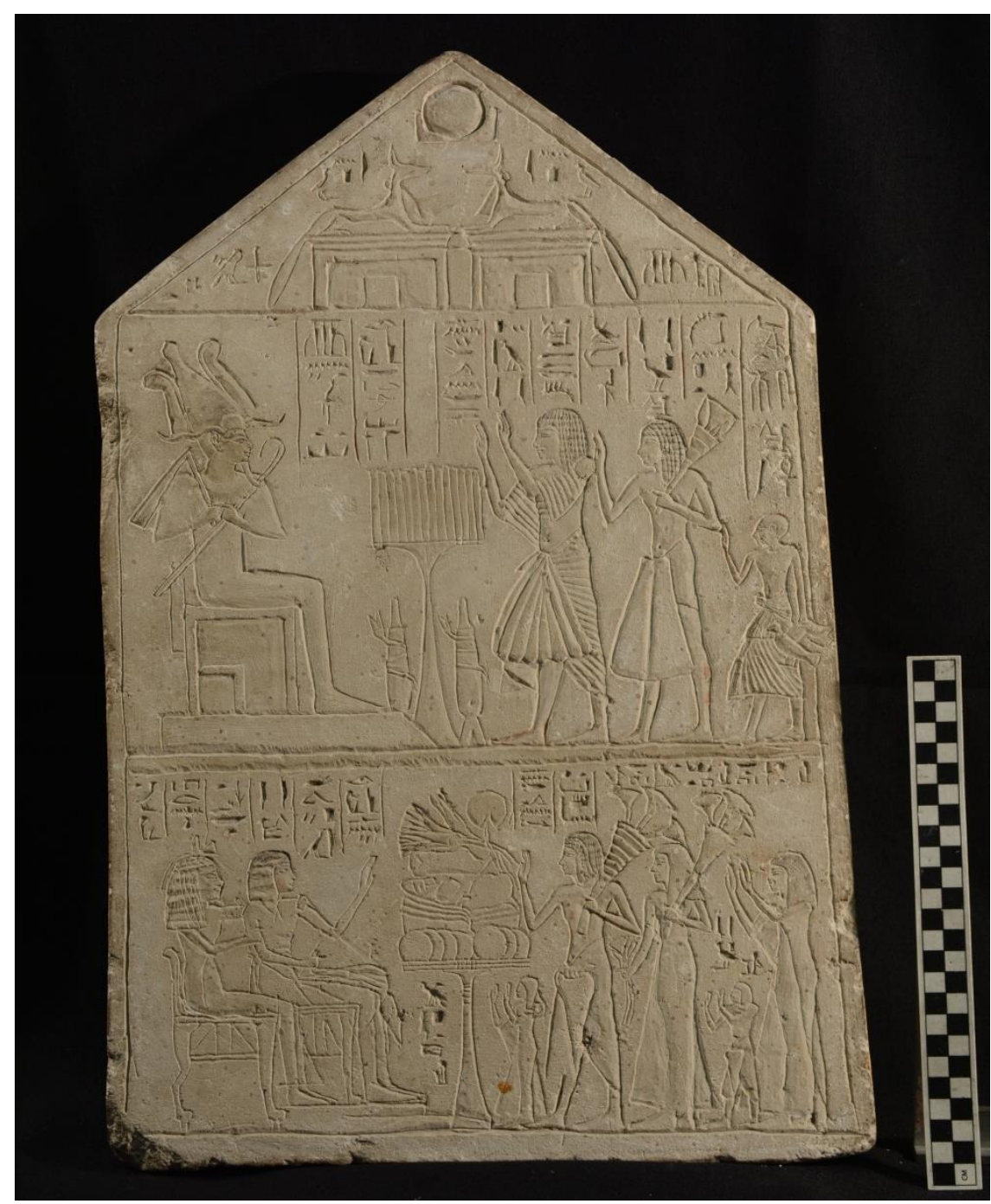

Fig.1. The Pyramidion Stela of Pi3y@ the Grand Egyptian Museum 


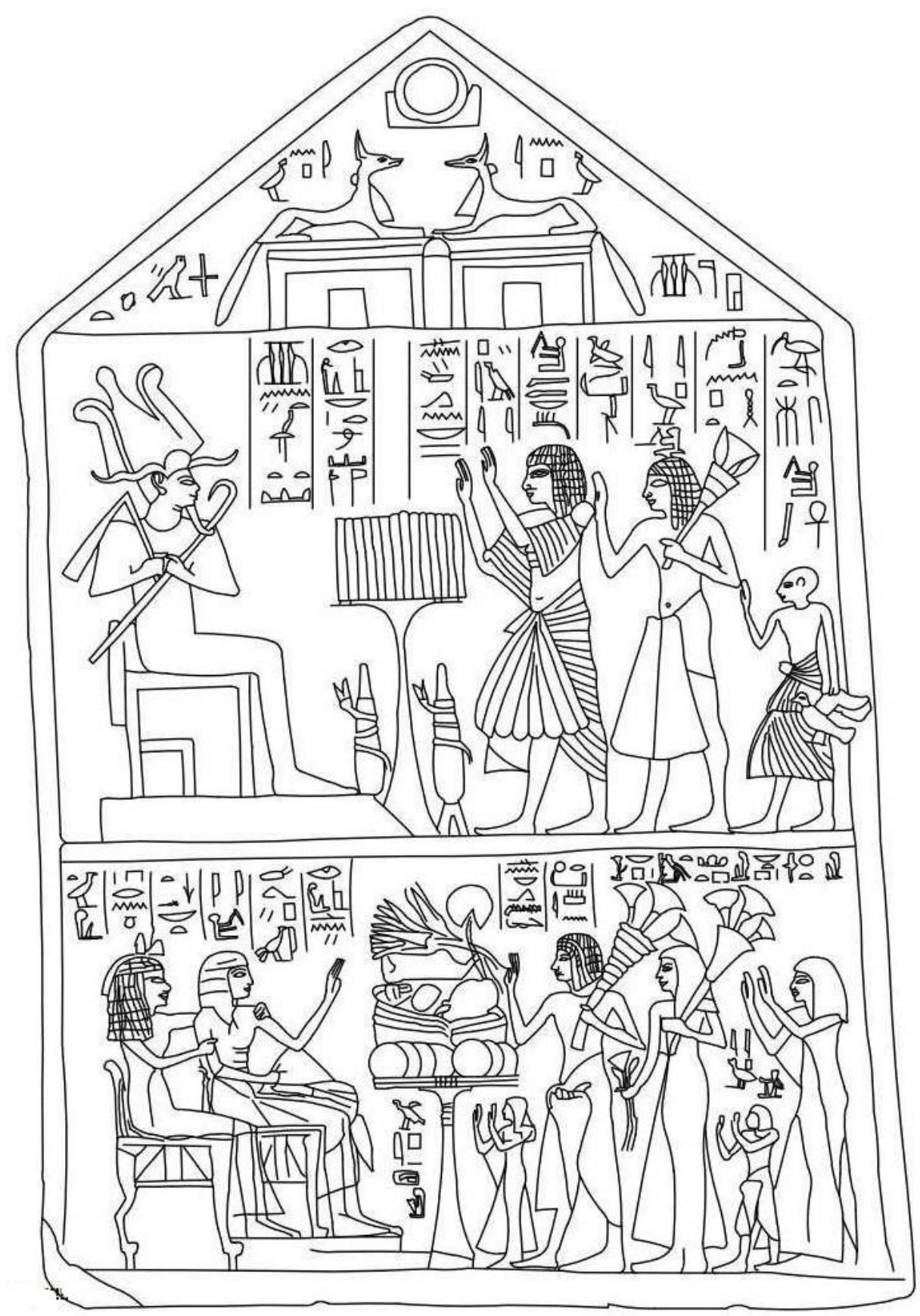

Fig.2. Line drawing of the Pyramidion Stela of Pi3y (by: Mohamed Ragab Ibrahim) 


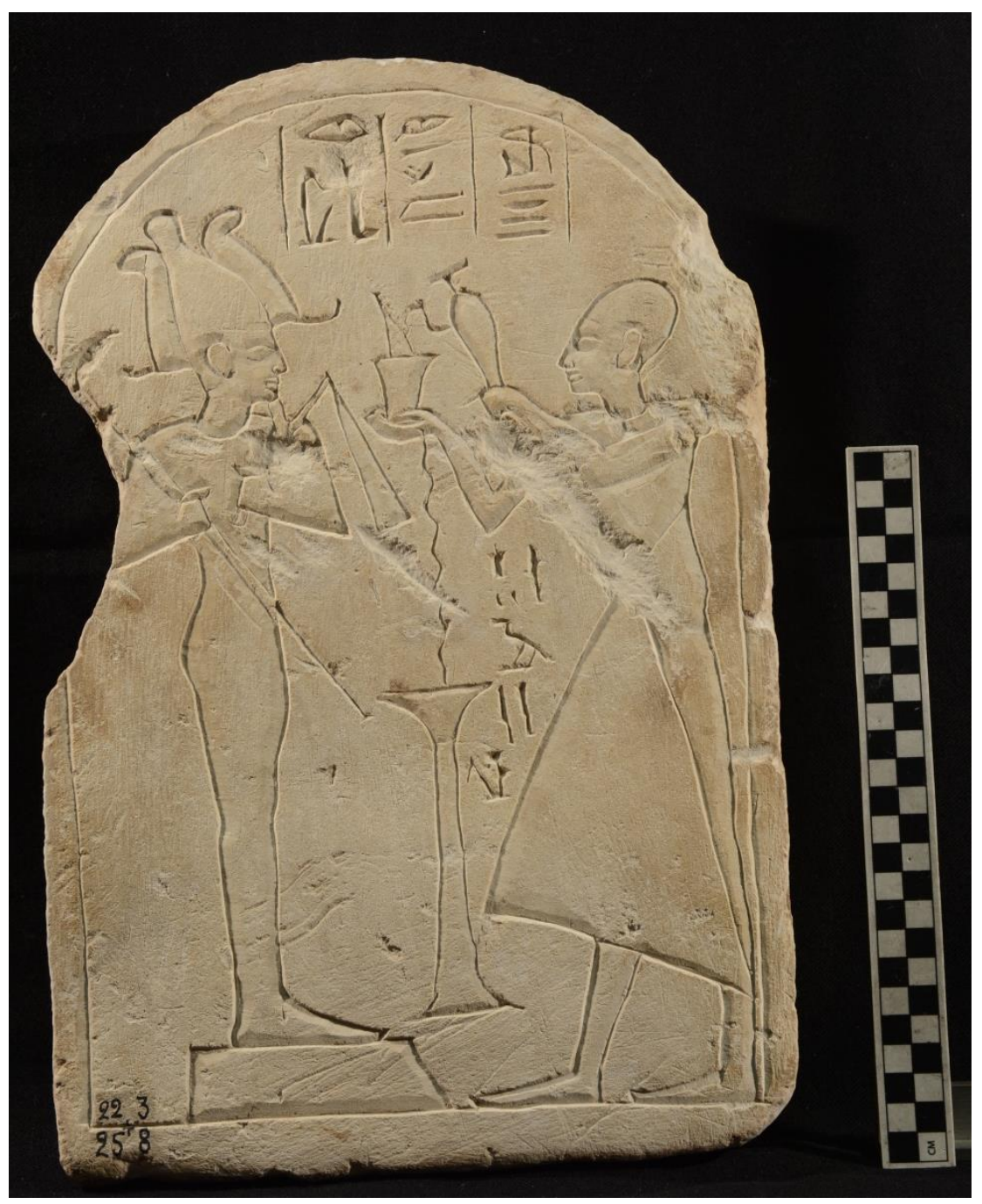

Fig.3. The Rounded-top Stela of Pi3y@ the Grand Egyptian Museum 


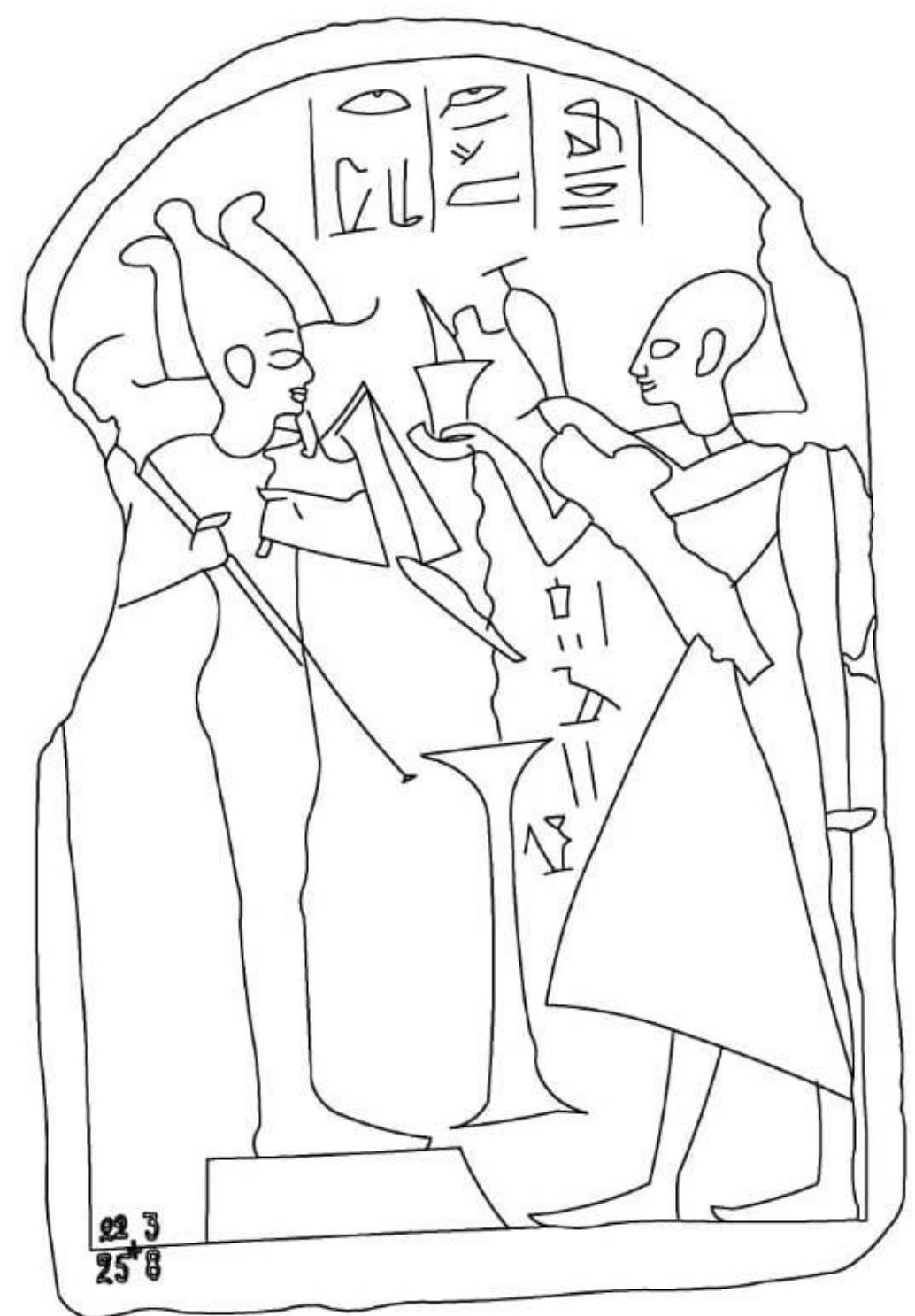

Fig.4. Line drawing of the Rounded-top Stela of Pi3y (by: Mohamed Ragab Ibrahim) 